\title{
Glass Formation of Null-Matrix Cu-Hf-(Zr, Ti) Alloys
}

\author{
Octavio Lozada-Flores ${ }^{a}$, Ignacio Alejandro Figueroa ${ }^{a}$ (D) \\ anstituto de Investigaciones en Materiales, Universidad Nacional Autónoma de México, Circuito exterior, \\ Ciudad Universitaria, Coyoacán, Ciudad de México, México.
}

Received: June 28, 2019; Revised: August 29, 2019; Accepted: September 18, 2019

\begin{abstract}
An approach following the null-matrix, $\mathrm{Ti} / \mathrm{Zr}$ ratio of 2.08 , for neutron diffraction was used to calculate the glass formation in $\mathrm{Cu}$-Ti-(Hf,Zr) alloys. The $\mathrm{Cu}_{55} \mathrm{Zr}_{14.6} \mathrm{Ti}_{30.4}, \mathrm{Cu}_{61.48} \mathrm{Hf}_{18.52} \mathrm{Zr}_{6.48} \mathrm{Ti}_{13.52}$, $\mathrm{Cu}_{58.1} \mathrm{Hf}_{16.9} \mathrm{Zr}_{8.1} \mathrm{Til}_{6.9}$ and $\mathrm{Cu}_{52.46} \mathrm{Hf}_{14.2} \mathrm{Zr}_{10.8} \mathrm{Ti}_{22.54}$ compositions (at. \%), were calculated and prepared by argon arc melting. Copper die suction casting was employed to produce conical shaped samples with diameters decreasing from $8 \mathrm{~mm}$ to $1 \mathrm{~mm}$. X-ray diffraction and Neutron Diffraction were used to characterize the alloys with the aim of obtaining the critical glassy diameter, dc, of the alloys. The results showed the composition with the biggest $d_{c}$ was the $\mathrm{Cu}_{61.48} \mathrm{Hf}_{18.52} \mathrm{Zr}_{6.48} \mathrm{Ti}_{3.52}$ alloy, with $d c=6 \mathrm{~mm}$. Thermal parameters were obtained by differential scanning calorimetry and the maximum values for glass transition temperature, $T_{g},(747 \mathrm{~K})$, crystallization temperature, $T_{x}$, $(772 \mathrm{~K})$, solidus temperature, $\mathrm{T}_{\mathrm{m}},(1152 \mathrm{~K})$ and liquidus temperature, $\mathrm{T}_{1},(1230 \mathrm{~K})$ corresponded to the $\mathrm{Cu}_{61.48} \mathrm{Hf}_{18.52} \mathrm{Zr}_{6.48} \mathrm{Ti1}_{3.52}$ composition. The results also showed that the parameters obtained from thermal analysis did not correlate with the GFA obtained. However, a good correlation of GFA and $d_{c}$ was found by means of the topological model, where the highest \% packing efficiency $(53.57 \%)$ was found for the $\mathrm{Cu}_{61.48} \mathrm{Hf}_{18.52} \mathrm{Zr}_{6.48} \mathrm{Ti}_{13.52}$ alloy, which also showed the highest $d_{c}$ value with $6 \mathrm{~mm}$.
\end{abstract}

Keywords: metallic glasses, rapid-solidification, calorimetry, neutron diffraction, X-ray diffraction, topological model.

\section{Introduction}

In recent years, the research in metallic glass formation has been focused on $\mathrm{Cu}-\mathrm{Hf}$ and $\mathrm{Cu}-\mathrm{Zr}$ based bulk metallic glasses (BMG, typically referred to a critical casting thickness larger than $1 \mathrm{~mm}$ ) due to its critical glassy diameter, $d_{c}$, and the low critical cooling rate, $R$, required for vitrification. The glass forming ability, GFA, of binary alloys $\mathrm{Cu}_{100-\mathrm{x}} \mathrm{Hf}_{\mathrm{x}}$ $(x=50,45,40,35,3024$ at.\%) has been investigated and the maximum reliable, $d_{c}$, obtained was $1 \mathrm{~mm}$ for the $\mathrm{Cu}_{65} \mathrm{Hf}_{35}$ alloy ${ }^{1}$. The bulk glass formation in binary $\mathrm{Cu}-\mathrm{Zr}$ system was studied for $\mathrm{Cu}_{100-\mathrm{x}} \mathrm{Zr}_{\mathrm{x}}(\mathrm{x}=34,36,38.2,40$ at.\%) by the copper mold casting method and the conclusion was that the GFA had a strong compositional dependence ${ }^{2}$. Besides, in case of the ternary $\mathrm{Cu}-\mathrm{Hf}-\mathrm{Ti}$ alloys, an exhaustive study has been carried out and the results showed an improvement in the critical diameter, $d_{c}$. The highest $d_{c}$ obtained was $5 \mathrm{~mm}$ for the $\mathrm{Cu}_{56} \mathrm{Hf}_{25} \mathrm{Ti}_{19}$ and $\mathrm{Cu}_{55} \mathrm{Hf}_{26} \mathrm{Ti}_{19}$ alloy compositions ${ }^{3}$. In addition, the glass formation and mechanical properties in the $\mathrm{Cu}-\mathrm{Zr}$-Hf-Ti, $\mathrm{Cu}-\mathrm{Zr}$-Ti and $\mathrm{Cu}-\mathrm{Hf}-\mathrm{Ti}$ systems for certain compositions were studied in detail ${ }^{4,5}$. On the other hand, it has been reported that additions of small amounts of B, $\mathrm{Y}$ and $\mathrm{Si}$ increased the GFA in these alloys ${ }^{6,7}$. Certainly, there is a compositional range in the $\mathrm{Cu}-\mathrm{Hf}-\mathrm{Ti}$ system in which BMG can be produced, thus, it is very important to propose a method for predicting the formation of BMG in specific compositions to facilitate the study of these materials.
A number of thermal parameters have been proposed to determine the origin of GFA, i.e. the reduced glass transition temperature $\mathrm{T}_{\mathrm{rg}}=\mathrm{T}_{\mathrm{g}} / \mathrm{T}_{1}$ (where $\mathrm{T}_{\mathrm{g}}$ and $\mathrm{T}_{1}$ are glass transition and liquidus temperatures, respectively) ${ }^{8}$, the supercooled liquid region, $\Delta \mathrm{T}_{\mathrm{x}}=\mathrm{T}_{\mathrm{x}}-\mathrm{T}_{\mathrm{g}}$ (where $\mathrm{T}_{\mathrm{x}}=$ crystallization temperature) ${ }^{9}$, and the parameters $\gamma=\mathrm{T}_{\mathrm{x}} /\left(\mathrm{T}_{\mathrm{g}}+\mathrm{T}_{1}\right){ }^{10}, \gamma_{\mathrm{m}}=$ $\left(2 \mathrm{~T}_{\mathrm{x}}-\mathrm{T}_{\mathrm{g}}\right) / \mathrm{T}_{1}{ }^{11}$ and $\beta=\left(\mathrm{T}_{\mathrm{x}} * \mathrm{~T}_{\mathrm{g}}\right) /\left(\mathrm{T}_{1}-\mathrm{T}_{\mathrm{x}}\right)^{\wedge} 2^{12}$. It has been proven that these parameters could help to predict the GFA for some alloys; however, they present limitations that do not make it suitable to be applied in all systems. Additionally, some structural parameters and topological criteria have been used to explain the high GFA of bulk glass-forming alloys. Egami and Waseda proposed the atomic strain criterion to predict the GFA for binary systems ${ }^{13}$ and Miracle and co-workers proposed another topological criterion that considers only the geometry of the packing of spheres of different diameters ${ }^{14,15}$ to predict the best composition in a metallic system, in order to produce bulk metallic glasses. In the present work, following the null-matrix approach of $\mathrm{Ti} / \mathrm{Zr}$ ratio $=2.08$, for neutron diffraction, four new $\mathrm{Cu}$-Ti-(Hf,Zr) BMG were calculated and experimentally produced. X-ray diffraction and Neutron Diffraction techniques were used to characterize the alloys in order to obtain the $d_{c}$, of such alloys. Thermal parameters were obtained by deferential scanning calorimetry (DSC) and the $\%$ of Packing Efficiency was also calculated by means of a modified topological model ${ }^{15}$. 


\section{Experimental Procedures}

The compositions of the alloys proposed were calculated, as mentioned above, keeping the $\mathrm{Ti} / \mathrm{Zr}$ ratio equal to 2.08 . The alloy compositions calculated are shown in Table 1.

The alloy ingots were prepared by melting the pure elements, i.e. Hf( $99.8 \%$ pure), Ti (99.6 \% pure), $\mathrm{Cu}(99.99 \%$ pure) and $\mathrm{Zr}$ (99.2\% pure) with an atmosphere controlled arc furnace. In order to reduce the oxidation of pure elements, a Ti-gettered and high purity argon were used. Each ingot was re-melted at least five times with the aim of obtaining good chemical homogeneity. The alloy compositions represent the nominal values but the weight losses in melting were $<0.1 \%$. Copper die suction casting was employed to produce conical shaped samples with diameters decreasing from $8 \mathrm{~mm}$ to 1 $\mathrm{mm}$. Ribbon glassy samples were produced by chill-block melt spinning in a sealed helium atmosphere at a roll speed of $25 \mathrm{~m} / \mathrm{s}$ with an injection pressure of 0.4 bar and a nozzle orifice diameter of $0.8 \mathrm{~mm}$. The gap between the crucible and the copper wheel was approximately $5 \mathrm{~mm}$. The critical glassy diameter, $d_{c}$, of the cast alloys samples was obtained by X-ray diffraction (XRD) using Co radiation $(\lambda=1.78897$ $\AA$ ) in a diffractometter D5000, SIEMENS. Additionally, neutron diffraction scans were performed at $298 \mathrm{~K}$ up to 3 $\mathrm{mm}$ for the suction cast samples, with an incident neutron wavelength of $\approx 0.7 \AA$. The neutron diffraction patterns were taken with the samples in an evacuated bell jar (to avoid air scattering); plus a pattern of the empty bell jar to give the background scattering, and a cylindrical vanadium rod of $6 \mathrm{~mm}$ of diameter for normalization purposes. The glass transition $\left(\mathrm{T}_{\mathrm{g}}\right)$, crystallization $\left(\mathrm{T}_{\mathrm{x}}\right)$, solidus $\left(\mathrm{T}_{\mathrm{m}}\right)$ and liquidus $\left(\mathrm{T}_{1}\right)$ temperatures were determined by differential scanning calorimetry (DSC) using a TA SDT Q600 calorimeter at a heating rate of $0.33 \mathrm{~K} / \mathrm{s}$ in alumina crucibles. The DSC measurements were calibrated using a fresh zinc standard, giving an accuracy of $\pm 0.2 \mathrm{~K}$ and $\pm 0.02 \mathrm{~mW}$.

\section{Results and Discussion}

The composition of the ternary $\mathrm{Cu}-\mathrm{Zr}$-Ti alloy here proposed has almost the same composition of the ternary $\mathrm{Cu}$-Hf-Ti alloy reported in the literature, this is because the lattices parameter of $\mathrm{Hf}$ and $\mathrm{Zr}$ elements are approximately the same $\left(\mathrm{a}_{0}=3.1946 \AA, \mathrm{b}_{0}=5.0511 \AA\right.$ and $\mathrm{c}_{0}=1.5811 \AA$ for Hf; $\mathrm{a}_{0}=3.2312 \AA, \mathrm{b}_{0}=5.1477 \AA$ and $\mathrm{c}_{0}=1.5931 \AA$ for $\mathrm{Zr}^{16}$, this should result in a closely isomorphous replacement.
As mentioned in the experimental section, the ternary $\mathrm{Cu}$ $\mathrm{Zr}-\mathrm{Ti}$ and quaternary $\mathrm{Cu}-\mathrm{Hf}-\mathrm{Zr}-\mathrm{Ti}$ alloys were calculated by keeping the $\mathrm{Ti} \mathrm{Zr}$ ratio $=2.08$. Based on the above, and according to the reported alloys with high GFA 1 , the resulting ternary composition with 55 at.\% of $\mathrm{Cu}$ was the $\mathrm{Cu}_{55} \mathrm{Zr}_{14.6} \mathrm{Ti}_{30.4}$ alloy. For quaternary alloys, the same procedure was used to propose three compositions that might show a fully glassy phase, i.e. above $1 \mathrm{~mm}$ in diameter. A comparison of the curves obtained by means of neutron diffraction for all alloys is shown in Figure 1. The four alloys showed the characteristic features commonly observed in most metallic glasses, namely a sharp first peak, a second peak with a shoulder on the high Q side and well developed oscillations out to $\mathrm{Q}_{\max }$. This proved that the proposed alloys did form BMGs with $d_{c} \geq 2 \mathrm{~mm}$.

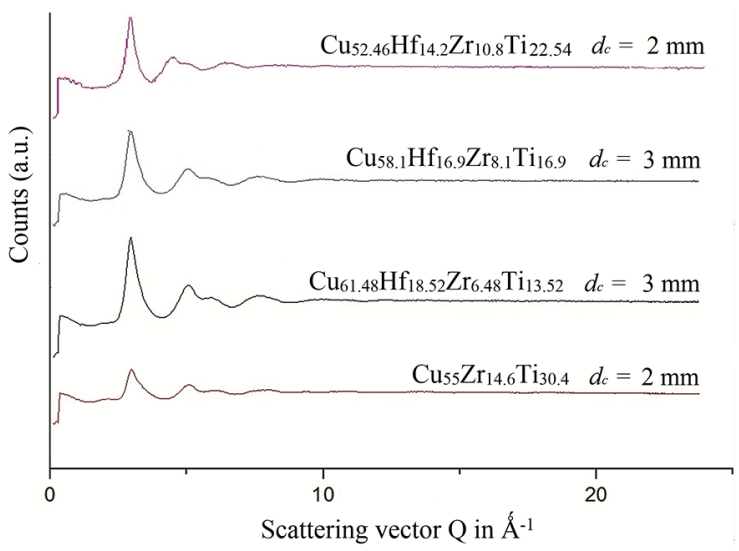

Figure 1. Neutron diffraction pattern for the alloys analyzed by neutron diffraction with $d_{c} \geq 2 \mathrm{~mm}$.

As the samples that were analyzed by neutron diffraction had diameters of 1, 2 and $3 \mathrm{~mm}$, it was suspected that $d$. was larger. Therefore, X-Ray analysis was performed for samples of up to $8 \mathrm{~mm}$ in diameter, in order to obtain the $d_{c}$. These results are shown in Figure 2. The proposed ternary $\mathrm{Cu}_{55} \mathrm{Zr}_{14.6} \mathrm{Ti}_{30.4}$ alloy composition is very similar to $\mathrm{Cu}_{55} \mathrm{Hf}_{15} \mathrm{Ti}_{30}$ 3 , both had a $d_{c}=2 \mathrm{~mm}$. In the case of quaternary alloys, the $\mathrm{Cu}_{61.48} \mathrm{Hf}_{18.52} \mathrm{Zr}_{6.48} \mathrm{Ti}_{13.52}$ alloy displayed a $d_{c}=6 \mathrm{~mm}$, which is the maximum value obtained for the investigated alloys. By increasing the amount of titanium (keeping the $\mathrm{Ti}_{2.08} \mathrm{Zr}_{1}$ ratio), it was observed that $d_{c}$ tended to decrease. This was observed for the $\mathrm{Cu}_{58.1} \mathrm{Hf}_{16.9} \mathrm{Zr}_{8.1} \mathrm{Ti}_{16.9}$ alloy with a $d_{c}=5 \mathrm{~mm}$ and finally the $\mathrm{Cu}_{52.46} \mathrm{Hf}_{14.2} \mathrm{Zr}_{10.8} \mathrm{Ti}_{22.54}$ alloy with $d_{c}=2 \mathrm{~mm}$ (lowest $d_{c}$ value obtained).

Table 1. Alloys composition studied

\begin{tabular}{ccccccc}
\hline Sample & $\mathrm{Alloy}$ & $\mathrm{Cu}($ at. \%) & $\mathrm{Hf}($ at. \%) & $\mathrm{Zr}$ (at. \%) & $\mathrm{Ti}($ at. \%) & $\mathrm{Ti} / \mathrm{Zr}$ \\
\hline M1 & $\mathrm{Cu}_{55} \mathrm{Zr}_{14.6} \mathrm{Ti}_{30.4}$ & 55 & 0 & 14.6 & 30.4 & $30.4 / 14.6$ \\
$\mathrm{M} 2$ & $\mathrm{Cu}_{61.48} \mathrm{Hf}_{18.52} \mathrm{Zr}_{6.48} \mathrm{Ti}_{13.52}$ & 61.48 & 18.52 & 6.48 & 13.52 & $13.52 / 6.48$ \\
M3 & $\mathrm{Cu}_{58.1} \mathrm{Hf}_{16.9} \mathrm{Zr}_{8.1} \mathrm{Ti}_{16.9}$ & 58.1 & 16.9 & 8.1 & 16.9 & $16.9 / 8.1$ \\
M4 & $\mathrm{Cu}_{52.46} \mathrm{Hf}_{14.2} \mathrm{Zr}_{10.8} \mathrm{Ti}_{22.54}$ & 52.46 & 14.2 & 10.8 & 22.54 & $22.54 / 10.8$ \\
\hline
\end{tabular}




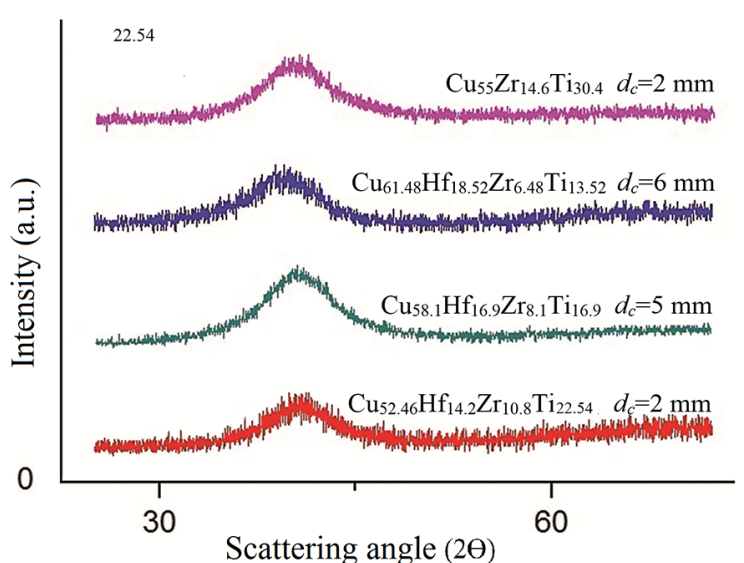

Figure 2. XRD diffraction pattern from the cross section withs dc of the proposed alloy

The chemical mixing enthalpy $\left(\Delta \mathrm{H}^{\text {mix }}\right)$ was calculated based on the extended regular solution model using the reported values in reference 17 :

$$
\Delta \mathrm{H}^{m i x}=\sum_{\substack{i=1 \\ i \neq j}}^{3} \Omega_{i j} c_{i} c_{j}
$$

Where $\Omega_{i j}$ is the regular solution interaction parameter between $\mathrm{i}$-th and $\mathrm{j}$-th elements, and is assumed to be constant in this case. $c_{i, j}$ is the composition of $\mathrm{i}$ and $\mathrm{j}$ elements. According to Miedema's macroscopic model for binary liquid alloys ${ }^{18}, \Omega_{i j}=4\left(\Delta \mathrm{H}^{\mathrm{mix}}\right)$. The coefficient " 4 " is due to the definition at the equiatomic composition in a binary A-B system. Table 2 shows the $\Delta \mathrm{H}^{\text {mix }}$ for the proposed alloys and their respective $d_{c}$. The values obtained do not follow a trend over $d_{c}$, since the alloy with highest $d_{c}$ $(6 \mathrm{~mm})$, of the quaternary alloys, did not show the most negative value of $\Delta \mathrm{H}^{\text {mix }}$, which corresponds to $d_{c}=5 \mathrm{~mm}$ for the $\mathrm{Cu}_{58.1} \mathrm{Hf}_{16.9} \mathrm{Zr}_{8.1} \mathrm{Ti}_{16.9}$ allow with $\Delta \mathrm{H}^{\text {mix }}=-14.54 \mathrm{~kJ}$ $\mathrm{mol}^{-1}$. However, it can be considered that the $\Delta \mathrm{H}^{\text {mix }}$ values are very similar between the three alloys, despite the wide variation in $d_{c}$ values.
Since no correlation was found between the obtained $d_{c}$ and the chemical mixing enthalpy values, and in order to attempt to understand the GFA of the studied alloys, several parameters were calculated from the values obtained by the DSC. Figure 3, shows the DSC curves obtained for the investigated alloys. The magnitude of $T_{g}, T_{x}, T_{m}$ and $T_{1}$ parameters and some GFA indicators like $\Delta \mathrm{T}_{\mathrm{x}}{ }^{9}, \mathrm{~T}_{\mathrm{rg}}{ }^{8}, \gamma^{10}$, $\gamma_{\mathrm{m}}{ }^{11}$ and $\beta^{12}$ are shown in Table 3 .

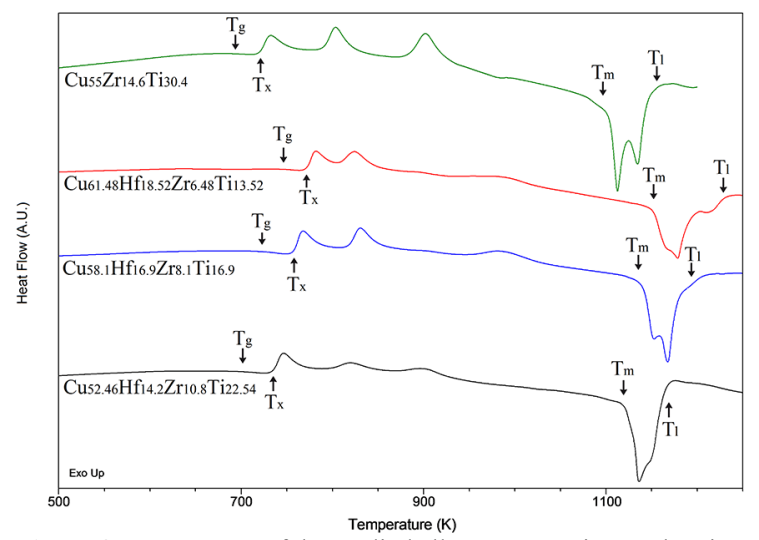

Figure 3. DSC curves of the studied alloys at a continuous heating rate of $0.33 \mathrm{~K} / \mathrm{min}$

Figure 4 shows the changes in $\Delta \mathrm{T}_{\mathrm{x}}, \mathrm{T}_{\mathrm{rg}}, \gamma, \gamma_{\mathrm{m}}, \beta$ parameters and $d_{c}$ as a function of Ti. Generally, the $\Delta \mathrm{T}_{\mathrm{x}}$ parameter has been related to GFA 11 and can be expressed as GFA $\sim \Delta \mathrm{T}_{\mathrm{x}}$. However, for these alloys, at $d_{c}=6 \mathrm{~mm}$ (the highest obtained value), the magnitude of $\Delta \mathrm{T}_{\mathrm{x}}$ was the lowest. It was also observed that as $d_{c}$ values increased, $\Delta \mathrm{T}_{x}$ decreased. For that, the GFA of the $\mathrm{Cu}-\mathrm{Hf}-$ $\mathrm{Zr}$-Ti proposed alloys is not reflected by the $\Delta \mathrm{T}_{\mathrm{x}}$ parameter. On the other hand, the minimum values for the $\gamma, \gamma_{\mathrm{m}}, \beta$ parameters corresponded to a $d_{c}=6 \mathrm{~mm}$. The highest values of these parameters were obtained for the alloy with $d_{c}=5 \mathrm{~mm}$ and finally, these values decreased down to $d_{c}=2 \mathrm{~mm}$. Therefore, the $\gamma, \gamma_{\mathrm{m}}$, $\beta$ parameters did not show a significant correlation with GFA.

Table 2. Analyzed alloys with their $\mathrm{dc}$ and $\Delta \mathrm{H}^{\mathrm{mix}}$ values

\begin{tabular}{ccc}
\hline Composition & $d_{c}(\mathrm{~mm})$ & $\Delta \mathrm{H}^{\text {mix }}\left(\mathrm{kJ} \mathrm{mol}^{-1}\right)$ \\
\hline $\mathrm{Cu}_{55} \mathrm{Zr}_{14.6} \mathrm{Ti}_{30.4}$ & 2 & -13.41 \\
$\mathrm{Cu}_{61.48} \mathrm{Hf}_{18.52} \mathrm{Zr}_{6.48} \mathrm{Ti}_{13.52}$ & 6 & -14.40 \\
$\mathrm{Cu}_{58.1} \mathrm{Hf}_{16.9} \mathrm{Zr}_{8.1} \mathrm{Ti}_{16.9}$ & 5 & -14.54 \\
$\mathrm{Cu}_{52.46} \mathrm{Hf}_{14.2} \mathrm{Zr}_{10.8} \mathrm{Ti}_{22.54}$ & 2 & -14.53 \\
\hline
\end{tabular}

Table 3. Critical diameters and thermal parameters of the studied alloys

\begin{tabular}{cccccccccccc}
\hline & $\mathrm{dc}(\mathrm{mm})$ & $\mathrm{T}_{\mathrm{g}}(\mathrm{K})$ & $\mathrm{T}_{\mathrm{x} 1}(\mathrm{~K})$ & $\mathrm{T}_{\mathrm{m}}(\mathrm{K})$ & $\mathrm{T}_{1}(\mathrm{~K})$ & $\Delta \mathrm{T}_{\mathrm{x}}(\mathrm{K})$ & $\mathrm{T}_{\mathrm{rg}}$ & $\gamma$ & $\gamma \mathrm{m}$ & $\mathrm{K}_{\mathrm{gl}}$ & $\beta$ \\
\hline M1 & 2 & 692 & 721 & 1103 & 1148 & 29 & 0.603 & 0.392 & 0.653 & 0.076 & 2.736 \\
$\mathrm{M} 2$ & 6 & 747 & 772 & 1152 & 1230 & 25 & 0.607 & 0.390 & 0.648 & 0.066 & 2.749 \\
M3 & 5 & 722 & 757 & 1141 & 1183 & 35 & 0.610 & 0.397 & 0.669 & 0.091 & 3.012 \\
M4 & 2 & 693 & 735 & 1120 & 1163 & 42 & 0.596 & 0.396 & 0.668 & 0.109 & 2.781 \\
\hline
\end{tabular}




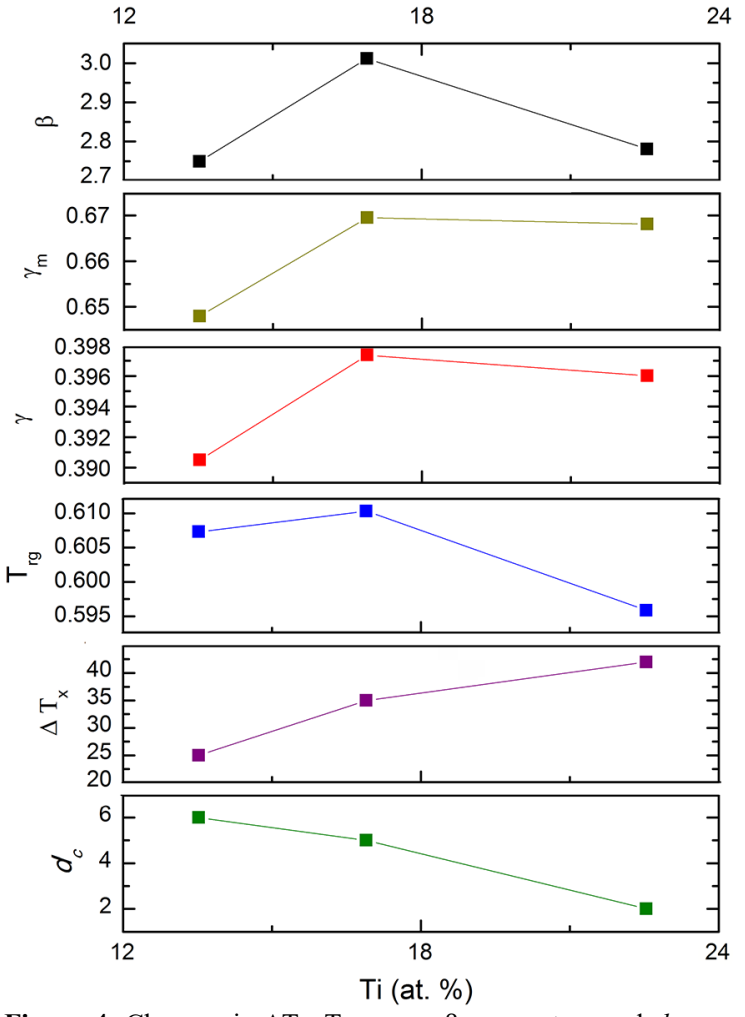

Figure 4. Changes in $\Delta \mathrm{T}_{\mathrm{x}}, \mathrm{T}_{\mathrm{rg}}, \gamma, \gamma_{\mathrm{m}}, \beta$ parameters and $d_{c}$ as a function of $\mathrm{Ti}($ at. $\%)$

On the other hand, the $\mathrm{T}_{\mathrm{rg}}$ parameter did show the best correlation with the GFA, because, unlike the previous ones, the lowest value obtained was closely related to the lowest $d_{c}$ value (2 $\mathrm{mm}$ ) and at $d_{c}=5 \mathrm{~mm}$ and $d_{c}=6 \mathrm{~mm}$ the values obtained for $\mathrm{T}_{\mathrm{rg}}$ are almost the same (0.610 and 0.607 , respectively). In summary, the GFA of the proposed alloys is not well described by $\Delta \mathrm{T}_{\mathrm{x}}, \mathrm{T}_{\mathrm{rg}}, \gamma, \gamma_{\mathrm{m}}$ and $\beta$ parameters.

As the physical concept of null-matrix was used, an attempt to explain such correlating was also explored. Since positive neutron scattering length of a nucleus is the result of the repulsive potential of the neutron as it approaches the nucleus and the negative scattering length means the neutron is subjected to an attractive potential (a negative scattering length indicates that the Fermi pseudo-potential for the neutron scattering is attractive). The existence of positive and negative scattering lengths for atomic nuclei is somehow helping to improve the GFA of the alloys investigated. With these results, it was not possible to explain the GFA in terms of negative or positive scattering lengths.
This suggests that the topological and particularly the chemical order in these BMGs will be a major influence on the viscosity and diffusivity in the melt, as well as the crystal nucleation and growth characteristics. If the partial pair distributions of these BMGs are obtained, these conjectures will be clarified (this results will be reported elsewhere in detail).

Using the topological model ${ }^{15}$, in order to understand the GFA, the preferred values $R^{*}$ were calculated by means of the ratio $(R)$ of the solute atom radius $(x)$ to the solvent atom radius $(y), R=x / y$. In the quaternary alloys, the atomic radii of the component atoms are: $\mathrm{Cu}=0.127 \mathrm{~nm}, \mathrm{Ti}=$ $0.146, \mathrm{Zr}=0.158 \mathrm{~nm}$ and $\mathrm{Hf}=0.167 \mathrm{~nm}^{14}$. Therefore $R_{Z r}$ ${ }_{C u}=1.24, R_{T i / C u}=1.15$ and $R_{H / C u}=1.31$. With these values, the dimensions of the cluster lattice unit cell length $\left(A_{o}\right)$ were calculated. Since the chemical composition of the alloys is already defined, and using $\mathrm{Zr}$ as the basis for calculation, the numbers of atoms per cluster lattice unit cell and the cluster-packing factor were calculated. Table 4 shows the obtained values for the proposed alloys and the $\mathrm{Cu}_{70.99} \mathrm{Zr}_{14.51} \mathrm{Hf}_{7.25} \mathrm{Ti}_{7.25}$ alloy ${ }^{19}$ calculated by means of the topological model, which according to the same, it would be the alloy with the maximum packing factor for the $\mathrm{Cu}$ $\mathrm{Hf}-\mathrm{Zr}$-Ti alloy family. The criterion of having $\mathrm{Zr}$ as a base element is due to the ratio of number of atoms in the alloy was greater than 1 . These results could provide a possible explanation of the experimentally obtained $d_{c}$ values, as the highest value of packing efficiency percentage, coincides with the largest $d_{c}$ value. Although the viscosity of the alloys, just above the liquidus $\left(T_{l}\right)$ temperature was not obtained, it is thought that the alloy that showed the highest percentage of packing efficiency would have the highest viscosity value. If the magnitude of viscosity were high enough to difficult the movement and nucleation of atoms, the GFA of any alloy would be greatly enhanced.

\section{Conclusions}

By means of the null-matrix method it was possible to calculate the formation of BMG in the $\mathrm{Cu}-\mathrm{Ti}-(\mathrm{Zr}-\mathrm{Hf})$ alloy family. The $\mathrm{Cu}_{61.48} \mathrm{Hf}_{18.52} \mathrm{Zr}_{6.48} \mathrm{Ti}_{13.52}$ alloy showed the largest experimentally, $d_{c}$, with $6 \mathrm{~mm}$. The $\mathrm{Cu}_{58.1} \mathrm{Hf}_{16.9} \mathrm{Zr}_{8.1} \mathrm{Ti}_{16.9}$ and $\mathrm{Cu}_{52.46} \mathrm{Hf}_{14.2} \mathrm{Zr}_{10.8} \mathrm{Ti}_{22.533}$ alloys also showed a fully glassy phase, $d_{c}$, of 5 and $2 \mathrm{~mm}$, respectively. The GFA could not be explained in terms of the proposed thermal parameters neither by chemical mixing enthalpy, as they did not follow a trend as a function of $d_{c}$.

Table 4. Number of atoms per cluster lattice cell and packing efficiency \% of the calculated alloys

\begin{tabular}{ccc}
\hline Composition & Number of atoms per cluster lattice unit cell & Packing Efficiency (\%) \\
\hline $\mathrm{Cu}_{61.48} \mathrm{Hf}_{18.52} \mathrm{Zr}_{6.48} \mathrm{Ti}_{13.52}$ & 15.44 & 53.57 \\
$* \mathrm{Cu}_{70.99} \mathrm{Zr}_{14.51} \mathrm{Hf}_{7.25} \mathrm{Ti}_{7.25}$ & 13.79 & 43.59 \\
$\mathrm{Cu}_{58.1} \mathrm{Hf}_{16.9} \mathrm{Zr}_{8.1} \mathrm{Ti}_{16.9}$ & 12.35 & 43.23 \\
$\mathrm{Cu}_{52.46} \mathrm{Hf}_{14.2} \mathrm{Zr}_{10.8} \mathrm{Ti}_{22.533}$ & 9.26 & 32.86 \\
\hline
\end{tabular}

*According to the topological model ${ }^{19}$ 
The high glass formation of these alloys was attributed not only to their proximity to the quasi-ternary eutectic point, but also to the calculated cluster packing efficiency. The $\mathrm{Cu}_{61.48} \mathrm{Hf}_{18.52} \mathrm{Zr}_{6.48} \mathrm{Ti}_{13.52}$ alloy showed the largest $d_{c}(6 \mathrm{~mm})$ and the highest packing efficiency (53.57\%). These results showed that the experimentally obtained $d_{c}$ value coincides with the highest calculated packing efficiency percentage.

\section{Acknowledgements}

The authors would like to acknowledge the financial support from DGAPA-PAPIIT UNAM "IN102319" for funding the project. C. Flores, G. A. Lara-Rodriguez, F. Silvar, A. Tejeda, O. Novelo, C. Ramos, R. Reyes, A. Lopez V., J. M. Garcia and F. Garcia are also acknowledged for their technical support. "Por mi raza hablará el espíritu".

\section{References}

1. Figueroa IA, Plummer JD, Lara-Rodriguez GA, Novelo-Peralta $\mathrm{O}$, Todd I. Metallic glass formation in the binary $\mathrm{Cu}-\mathrm{Hf}$ system. Journal of Materials Science. 2013;48:1819-1825.

2. Xu D, Lohwongwatana B, Duan G, Johnson WL, Garland C. Bulk metallic glass formation in binary $\mathrm{Cu}$-rich alloy series $\mathrm{Cu}_{100-\mathrm{x}} \mathrm{Zr}_{\mathrm{x}}(\mathrm{x}=34,36,38.2,40$ at.\%) and mechanical properties of bulk $\mathrm{Cu}_{64} \mathrm{Zr}_{36}$ glass. Acta Materialia. 2004;52(9):2621-2624.

3. Figueroa IA, Báez-Pimiento S, Plummer JD, Novelo-Peralta O, Davies HA, Todd I. A detailed study of metallic glass formation in copper-hafnium-titanium alloys. Acta Metallurgica Sinica. 2012;25(6):409-419.

4. Inoue A, Zhang W, Zhang T, Kurosaka K. High-strengh Cu-based bulk glassy alloys in $\mathrm{Cu}-\mathrm{Zr}$-Ti and $\mathrm{Cu}-\mathrm{Hf}-\mathrm{TI}$ ternary systems. Acta Materialia. 2001;49(14):2645-2652.

5. Inoue A, Zhang W, Zhang T, Kurosaka K. Cu-based bulk glassy alloys with good mechanical properties in $\mathrm{Cu}-\mathrm{Zr}$-Hf-Ti system. Materials Transactions. 2001;42(8):1805-1812.
6. Figueroa IA, Rawal R, Stewart P, Carrol PA, Davies HA, Jones $\mathrm{H}$, et al. Bulk glass formation and mechanical properties for $\mathrm{Cu}-\mathrm{Hf}-\mathrm{Ti}-\mathrm{M}(\mathrm{M}=\mathrm{B}, \mathrm{Y})$ alloys. Journal of Non-Crystalline Solids. 2007;353(8-10):839-841.

7. Figueroa IA, Davies HA, Todd I. High glass formability for $\mathrm{Cu}-\mathrm{Hf}-\mathrm{Ti}$ alloys with small additions of Y and Si. Philosophical Magazine: A. 2009;89(27):2355-2368.

8. Turnbull D. Under what conditions can a glass be formed. Contemporary Physics. 1969;10(5):473-488.

9. Inoue A. High strength bulk amorphous alloys with low critical cooling rates. Materials Transactions, JIM. 1995;36(7):866-875.

10. Lu ZP, Liu CT. A new glass-forming ability criterion for bulk metallic glasses. Acta Materialia. 2002;50(13):3501-3512.

11. Du XH, Huang JC, Liu CT, Lu ZP. New criterion of glass forming ability for bulk metallic glasses. Journal of Applied Physics. 2007;101(8):086108.

12. Yuan ZZ, Bao LB, Lu Y, Zhang CP, Yao L. A new criterion for evaluating the glass-forming ability of bulk glass forming alloys. Journal of Alloys and Compounds. 2008;459(1-2):251-260.

13. Egami T, Waseda Y.Atomic size effect on the formability of metallic glasses. Journal of Non-Crystalline Solids. 1984;64(1-2):113-134.

14. Miracle DB. The efficient cluster packing model - An atomic structural model for metallic glasses. Acta Materialia. 2006;54(16):4317-4336.

15. Miracle DB. A structural model for metallic glasses. Nature Materials. 2004;3(10):697-702.

16. Pearson WB. A handbook of lattice spacings and structures of metals and alloys. Oxford: Pergamon Press; 1958.

17. Takeuchi A, Inoue A. Calculations of mixing enthalpy and mismatch entropy for ternary amorphous alloys. Materials Transactions, JIM. 2000;41(11):1372-1378.

18. Boer FR, Mattens WCM, Boom R, Miedema AR, Niessen AK. Cohesion in metals: Transition Metal Alloys. Netherlands: North-Holland; 1988.

19. Soto CEN, Vargas IAF, Velázquez JRF, Rodriguéz GAL, Matínez JAV. Composition, elastic property and packing efficiency predictions for bulk metallic glasses in binary, ternary and quaternary systems. Materials Research. 2016;19(2):285-294. 